\title{
Cellular Localization of Guidance Cues in the Establishment of Retinotectal Topography
}

\author{
Roger W. Davenport, Edda Thies, and Phillip G. Nelson \\ Laboratory of Developmental Neurobiology, National Institute of Child Health and Human Development, National Institutes \\ of Health, Bethesda, Maryland 20892
}

Topographic projections of the nervous system are essential to numerous brain functions. They arise during development as a result of encounters between projecting growth cones and particular target cells. Cellular localization of guidance cues can indicate the sequential processes involved in establishment of such topography. The map formed by retinal ganglion cells on their target nuclei has served widely as a model system to investigate mechanisms underlying the highly precise and stereotypic connectivity of the nervous system. To investigate cellular localization of guidance cues in the developing retinotectal system, a three-compartment chamber was created to delimit areas where cultured embryonic chick retinal ganglion axons and tectal cells encounter one another and guidance behavior could be readily assessed. Whereas explants from nasal retinae extended fibers across their natural target population, fibers from temporal regions of retinae failed to invade areas of growing posterior tectal cells. This preservation of relevant guidance information on living cell populations enabled an evaluation of retinal ganglion cell growth cone behavior after encounter with individual tectal cells. Posterior tectal neurons appeared selectively repulsive for temporal retinal ganglion cel growth cones, causing growth cone collapse and retraction. On the contrary, neuroepithelial cells from all regions of the tectum attenuated retinal ganglion axon extension, without inducing sudden retraction. Nasal growth cones traversed or tracked more often along neuroepithelial cells from their natural target area, potentially indicating a second set of guidance cues possibly localized to posterior glia. Together, these differential interactions suggest that development of retinotectal topography critically depends on cell-specific cues, which are distributed selectively on particular populations of target cells.

Key words: retinotectal; topographic projection; growth cone; neuronal development; filopodia; navigation; guidance; repulsion; retraction
In the developing visual system, processes regulating establishment of topography guide growth cones of retinal ganglion cells on their target nuclei and govern synaptic and arbor remodeling until a highly stereotypic projection is formed (Udin and Fawcett, 1988; Constantine-Paton et al., 1990; Mey and Thanos, 1992). In the projection from retina to optic tectum, retinal ganglion axons form connections such that the two-dimensional topography of the retinae is distributed across the tectum, e.g., axons from temporal and nasal retinae map onto anterior and posterior tecta, respectively. Guidance cues distributed across the tectum may be the first process in directing retinal ganglion cell growth cones on the tectum toward their ultimate target areas, either by attracting axons in "correct" directions or repelling them from "incorrect" directions (Sperry, 1963; Bonhoeffer and Gierer, 1984; Gierer, 1987; Fraser and Perkel, 1990; Sanes, 1993; Kaprielian and Patterson, 1994). Tectal guidance cues initially may slow outgrowth (Harris et al., 1987), then limit the exploratory area of retinal ganglion axons by the presence of components in posterior tecta, which are aversive to retinal ganglion axons from temporal retinae (Stahl et al., 1990b; Walter et al., 1990a). Repulsive guidance

Received July 27, 1995; rcvised Dec. 21, 1995; accepted Dec. 28, 1995.

This research was performed while R.W.D. held a National Research Council National Institute of Child Health and Human Development/National Institutes of Health Research Associateship. We thank Vance Lemmon, Ursula Drager, Elaine Neale, and Fritz Rathjen for their gift of antibodics. We cspecially thank Dr. Stephan Kroger, Vance Lemmon, Stefan Mcyer, Elainc Neale, Dianc Snow, and Cheri Williams for helpful comments and advice.

Correspondence should be addressed to Roger W. Davenport, Laboratory of Developmental Neurobiology, National Institutes of Health, 49/5 A32, Bethesda, MD 20892.

Copyright (C) 1996 Society for Neuroscience $\quad 0270-6474 / 96 / 162074-12 \$ 05.00 / 0$ component(s) are found in posterior tecta in numerous species (Walter et al., 1987a; Godement and Bonhoeffer, 1989; Johnston and Gooday, 1991; Vielmetter et al., 1991; Simon and O'Leary, 1992; Bastmeyer and Stuermer, 1993; Drescher et al., 1995) and could prevent temporal axons from extending far past their anterior tectal targets. Further guidance cues may provide support for directed outgrowth toward target layers (Yamagata and Sanes, 1995). In the chick, radial glia may provide the cues that enable retinal ganglion cell growth cones to turn and track along radial processes toward deeper retinorecipient layers of the tectum (Vanselow et al., 1989).

A major obstacle to understanding the mechanisms underlying retinotectal guidance has been the lack of cellular and molecular resolution of the influential developmental processes. Recently, candidate guidance molecules have been cloned (Cheng et al. 1995; Drescher et al., 1995), which certainly will lead to a more rapid understanding of retinotectal development. Still, the cellular substratum for activity-independent guidance cues remains unknown. For example, none of the assays using tectal membrane fragments that demonstrated the presence of repellent components in posterior tecta can indicate in which cells such components are expressed. Guidance cues may be provided by neuronal and/or non-neuronal target cells. Furthermore, it is unclear whether other guidance mechanisms might be masked by such repulsive factors when presented simultaneously in membrane fragment preparations (Simon and O'Leary, 1992; von Boxberg et al., 1993). Clearly, to localize guidance components in the visual system with cellular resolution, a single, functional system must be 


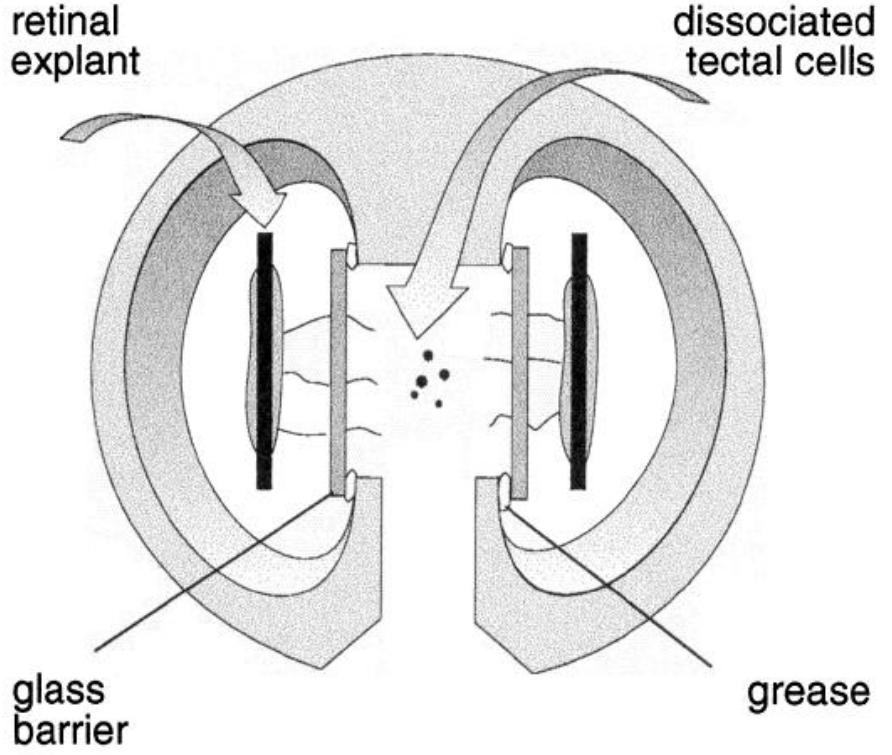

Figure 1. A Teflon-insert was used to define areas within an otherwise uniform culture dish in which retinal explants or dissociated tectal cells were placed. Laminin is coated across the entire culture surface before chamber placement. The chamber is then mounted to the culture surface by a thin layer of vacuum grease. A top view of the chamber indicates the three compartments, defined by glass coverslips, which are slid along greased edges until contacting the surface. Dissociated tectal cells are plated into the relatively leak-tight center compartment. After placing retinal explants into each side compartment, typically one from nasal and one from temporal regions of the retinae, the glass coverslip is raised or entirely removed to prevent physical hindrance to the elongating retinal ganglion axons. The ability to raise or remove the barrier represents the biggest advantage of the present chamber, although the relatively narrow width of the glass coverslip increases the probability of axon transversal and is virtually transparent.

examined with both neuronal and non-neuronal target cells present.

Coculture techniques that promote interaction of projecting axons with target cells enable direct examination of target-derived guidance. In the present investigation, a coculture method is devised such that embryonic chick retinal ganglion cell axons extend and subsequently encounter dissociated cells isolated from particular regions of optic tecta. Unequivocal expression of components repulsive for afferent fibers from temporal retinae are discovered in dissociated cultures from posterior tecta. Timelapse recordings of retinal ganglion cell growth cone encounters with individual tectal cells reveal that different cell classes from posterior tecta elicit distinct growth cone behaviors, suggesting that distinct guidance cues are localized to the different cell types.

\section{MATERIALS AND METHODS}

Chamber preparation. To preserve and present as many cellular guidance components as possible on embryonic optic tectal cells to elongating retinal ganglion fibers, a chamber was developed to allow elongating retinal ganglion axons to contact tectal cells in a consistent and predictable manner. The three-compartment chamber was designed by amalgamation of unique features of Campenot chambers (Campenot, 1977) and Klostermann chambers (Klostermann, 1993) and allowed separation of retinal and tectal cell cultures in an otherwise uniform culture dish (Fig. 1). A Teflon ring with an outer diameter of $2 \mathrm{~cm}$ was cut with Teflon guides. A small amount of grease (high vacuum; Dow Corning, Midland, MI) is spread at the edge of glass coverslips (No. 1) in alignment with the Teflon guides to allow the coverslips to remain attached to the Teflon insert and slide vertically along the guides. Thus, when coverslip barriers are positioned at their lowest extreme, three isolated compartments are created and different cells can be placed in each. After construction, chambers are autoclaved and ready for use. In most experiments, dissociated tectal cells were placed in the center compartment and retinal explants were then positioned in each side. Coverslip barriers were used to delimit areas of the culture dish during cell preparation and were removed before retinotectal encounters.

Coculture preparation. Cultures were prepared either on plastic dishes (35 mm, NUNC; PGC Scientific, Gaithersburg, MD) or glass inserts (No. 1; Carolina Supply, Burlington, NC) placed under a hole $(2.2 \mathrm{~cm})$ cut through the center of the culture dish and coated with laminin $(20 \mu \mathrm{g} / \mathrm{ml}$; Gibco, Gaithersburg, MD) for 0.5-3 hr. Plastic dishes were scratched with a micro-comb made of insect pins (Fields et al., 1990) in approximately half of the experiments used in the "chamber assay." The Teflon and glass insert was positioned approximately in the center of each dish, and glass barriers were lowered until contacting the bottom of the dish.

Optic tecta were removed from embryonic chickens [embryonic days 5-11 (E5-E11)] and separated into three sections. The middle section was discarded, and the anterior and posterior sections were mechanically dissociated in calcium-, magnesium-free Hanks' buffered salt solution (HBSS; Gibco) and subsequently concentrated by centrifugation and resuspended to a density of $4.5 \times 10^{6} \mathrm{cells} / \mathrm{ml}$ in DMEM/F12 medium (Gibco) with additional $10 \%$ fetal calf serum (Gibco). Dissociated cells $(100 \mu \mathrm{l})$ from either anterior or posterior tecta were dispersed into the center compartment and allowed to settle in the incubator $\left(37^{\circ} \mathrm{C}, 10 \%\right.$ $\mathrm{CO}_{2}$ ) for $0.5-1 \mathrm{hr}$. Before positioning retinae, side compartments were rinsed with medium to remove any contaminating tectal cells.

Retinal explants were prepared according to previously established methods (Halfter et al., 1983; Wizenmann et al., 1993; Baier and Klostermann, 1994). Briefly, retinae were removed from embryonic chickens (E5-E9), flat-mounted onto nitrocellulose filters (Sartorius, Bohemia, NY), and then cut into strips $0.40 \mathrm{~mm}$ wide along the dorsal-ventral axis to provide retinal explants specifically from either nasal or temporal retinae. Only retinal strips from the peripheral one-third of the retinae were used for experimentation; strips from the central one-third were discarded. Retinal strips were then positioned in the side compartment $\sim 2-3 \mathrm{~mm}$ from and parallel to the coverslip barrier. Subsequently, $\sim 4 \mathrm{ml}$ of medium were added to ensure that medium topped the chamber, and coverslip barriers were raised or removed. Tetrodotoxin (TTX; $1 \mu \mathrm{M}$ ) was added at this point in some preparations, as noted. Dishes were maintained in a humidified incubator at $37^{\circ} \mathrm{C}, 10 \% \mathrm{CO}_{2}$. In experiments evaluating the effect of molecules anchored by glycosyl phosphatidylinositol (GPI), phosphatidylinositol phospholipase C (PI-PLC; Boehringer Mannheim, Indianapolis, IN) was applied on the first and second day after explantation. To establish the effects on retinal and tectal cultures separately, 5-100 mU/ml PI-PLC was applied $24 \mathrm{hr}$ after explantation, and outgrowth was assessed 4 and $24 \mathrm{hr}$ later. In coculture experiments, some dishes received $5 \mathrm{mU} / \mathrm{ml}$, whereas other dishes received $60-100$ $\mathrm{mU} / \mathrm{ml}$. In these latter dishes, however, the PI-PLC was diluted to 20 $\mathrm{mU} / \mathrm{ml}$ after $\sim 4 \mathrm{hr}$. These concentrations were chosen to maximize enzyme activity while minimizing effects on outgrowth per se; therefore, the enzyme was diluted as soon as direct effects on retinal ganglion cell growth cones were observed. This paradigm exposed the cells for a limited time to relatively high concentrations of enzyme and allowed continued retinal outgrowth.

To visually asses the invasion of retinal ganglion cell axons into areas of dissociated tectal cells, retinal ganglion axons were subsequently labeled with Di- $\mathrm{IC}_{18}(3)$ (Molecular Probes, Eugene, OR). A stock solution of $\mathrm{Di}-\mathrm{IC}_{18}(3)$ (5\% in dimethyl sulfoxide) was diluted 1:1 with HBSS and dried onto nitrocellulose filters, then cut on a tissue chopper $(0.2 \mathrm{~mm}$ wide). Di-IC $\mathrm{IC}_{18}(3)$ strips were placed adjacent to the retinal explant directly on top of axons $\sim 48 \mathrm{hr}$ after explantation. These dishes were then returned to incubate for an additional $18 \mathrm{hr}$ and after fixation were viewed with epifluorescence illumination (see Immunohistochemistry).

Video microscopy. Cultures to be used for time-lapse microscopy were transported from the incubator and placed forthwith onto the stage of an inverted microscope (Nikon Diaphot, Melville, NY) previously warmed to $37^{\circ} \mathrm{C}$. Approximately $10 \% \mathrm{CO}_{2}$ was blown through a stage insert (Medical Systems, Greenvale, NY) around the lower portion of the dish to rise along the edge of the dish and under the lid and maintain medium $\mathrm{pH}$. Phase-contrast microscopy and Hoffmann modulation contrast microscopy were performed with 20 or $40 \times$ objectives and long working distance condensers. Images were collected via a charge-coupled device camera [Panasonic WV-BD404 (Secaucus, NJ), enhanced with a Hamamatsu DVS-3000 (Hamamatsu City, Japan)] at rates dependent on the media used to record them: every $1-4 \mathrm{sec}$ if recorded onto a 
time-lapse video cassette recorder (Panasonic AG-6730), every 15-180 sec if recorded directly onto a Macintosh computer via a frame grabber (LG3; Scion, Frederick, MD) using image analysis software (National Institutes of Health Image version 1.55, Wayne Rasband). For analysis and publication, image contrast and enhancement were performed using image software. Chi-square statistics were performed to assess growth cone responses after encounter with individual tectal cells.

Immunohistochemistry. To distinguish between neuronal and nonneuronal cell types in the dissociated cultures, a number of antibodies were applied. Fragment $\mathrm{C}$ of tetanus toxin (Calbiochem, La Jolla, CA) and monoclonal antibody 18.2.12.6 (described in Kenimer et al., 1983) was provided by W. Habig, Food and Drug Administration. Monoclonal antibodies $3 \mathrm{~A} 7$ to vimentin-associated antigens and $8 \mathrm{D} 9$ to avian $\mathrm{Ng}-$ CAM developed by V. Lemmon (Lemmon and McLoon, 1986) were obtained from $V$. Lemmon. A second monoclonal antibody to avian Ng-CAM (12-I-4E-311) (Chang et al., 1990) was obtained from F. Rathjen. Monoclonal antibody R5 to vimentin developed by U. Dräger (Dräger et al., 1984) was obtained from U. Dräger and B. Schlosshaver. Monoclonal antibodies developed by J. Sanes (H5 to vimentin; Herman et al., 1993) and J. Wood (RT-97 to neurofilament; Wood and Anderson, 1981) were obtained from the Developmental Studies Hybridoma Bank maintained by the Department of Pharmacology and Molecular Sciences, Johns Hopkins University School of Medicine, Baltimorc, MD, and the Department of Biological Sciences, University of Iowa, Iowa City, IA, under contract N()1-HD-2-3144 from the National Institute of Child Health and Human Development. Blocking sera and fluorescent secondary antibodies were obtained from Jackson Immunorescarch (West Grove, PA).

Except for tetanus toxin fragment $C$, which was applied to living cultures, all cultures were fixed at room temperature with freshly prepared $4 \%$ paraformaldehyde (Mallinckrodt, Paris, KY) for $\geq 2 \mathrm{hr}$, washed several times with PBS (Gibco), and incubated $10 \mathrm{~min}$ with $10 \%$ normal goat serum to block nonspecific antibody binding. Membranes were permeabilized with ice-cold methanol $\left(10 \mathrm{~min}\right.$ at $\left.4^{\circ} \mathrm{C}\right)$ when RT-97, anti-vimentin (H5 and R5), or 3A7 antibodies were used. Primary antibodies were added at their appropriate dilution in PBS for $\geq 1 \mathrm{hr}$ at room temperature. In cultures stained with more than one primary antibody, another wash with blocking solution was made before addition of the second primary antibody. Cultures were washed subsequently three times with PBS and a blocking solution to match the secondary antibody, either $10 \%$ normal goat or $10 \%$ normal donkey serum, for $\geq 30$ min before addition of appropriate fluorescent secondary antibodies. The following dilutions proved to be suitable for the identification of cell types: 8D9 was used at 1:250; RT-97 and anti-vimentin (H5 and R5) supernatant were used at full strength; and $3 \mathrm{~A} 7$ was used at 1:1000.

To stain with fragment $\mathrm{C}$, cultures were washed in a minimal salt solution [(in mM): $145 \mathrm{NaCl}, 4.5 \mathrm{KCl}, 1.8 \mathrm{CaCl}_{2}, 0.8 \mathrm{MgCl}_{2}, 10$ glucose, and 10 HEPES] containing $2 \%$ bovine serum albumin (RM/BSA) and incubated on a rocker platform in a mixture of fragment $\mathrm{C}$ (final concentration, $1.3 \mu \mathrm{g} / \mathrm{ml})$ and $18.2 .12 .16(1: 2000 ; 4 \mu \mathrm{g} / \mathrm{ml})$ in RM/BSA for 30 min at room temperature. After rinsing, CY3-labeled goat anti-mouse IgG (Jackson Immunoresearch) was added to the cultures for $30 \mathrm{~min}$.

Cultures were rinsed and stored in glycerol containing 20\% n-propyl gallate to prevent fluorescence photobleaching (Giloh and Sedat, 1982). Stained cells were vicwed and photographed using a Zciss Photomicroscope II and TMAX (3200 ASA) film (Kodak, Rochester, NY). Cultures stained with more than one primary antibody showed limited "bleed through" of brightly stained material, which can give the false appearance of slight positive staining.

\section{RESULTS}

\section{Temporal retinal ganglion fibers avoid dissociated posterior tectal cells}

To investigate cellular interactions that result in directed guidance of retinal ganglion axons during development of the topographic retinotectal projection, fibers extending from retinal explants were forced to encounter living, dissociated tectal cells (from either anterior or posterior regions) dispersed in the center compartment of a three-compartment chamber. A single retinal explant was placed in one side compartment, and a second retinal explant from the opposite portion of the same embryonic retinae was placed in the remaining side compartment. Each dish thus con- tained two retinal explants (one from temporal and one from nasal regions of the retinae) and dissociated tectal cells from either anterior or posterior regions of the tectum (Fig. 1). Physical barriers between these compartments were removed after plating but before outgrowth, so the three "compartments" simply represented three areas of an otherwise uniform culture dish. Retinal ganglion fiber extension into dissociated tectal cell areas was assessed by bright-field and fluorescent microscopy.

Consistent with previous studies using alternate techniques (Walter et al., 1987a; von Boxberg et al., 1993; Baier and Klostermann, 1994), fibers from temporal retinae did not invade posterior tectal cell areas, whereas other combinations of cell types allowed substantial invasion (Fig. 2). In $>100$ dishes, fibers from temporal retinae stopped at the edge of dissociated posterior tectal cells, whereas in the same dish fibers from nasal retinae grew well into the same tectal cells. When dishes were fixed $48 \mathrm{hr}$ after explantation, $\sim 24-30 \mathrm{hr}$ after the first contact with dissociated tectal cells, temporal retinal ganglion fibers appeared highly fasciculated, terminating in large bulbous endings as much as $50-100 \mu \mathrm{m}$ from the posterior tectal cell boundary (Fig. $2 A, B$ ). A few individual fibers and/or membranc material stretched from these bulbous endings to the posterior tectal cells, suggesting contact with tectal cells followed by tiber retraction. On the contrary, when anterior tectal cells were in the center compartment, temporal retinal ganglion fibers appeared less fasciculated and showed no indications of stopping at the boundary (Fig. $2 A^{\prime}, C$ ). Indeed, the outgrowth and invasion of temporal fibers into anterior tectal cells appeared very similar to that from nasal explants in which substantial extension occurred $(>1 \mathrm{~mm})$ across posterior or anterior tectal cells (Fig. 2D,E). Thus, the failure of retinal ganglion cell axons from temporal retinac to invade posterior tectal cells was strikingly different from the outgrowth pattern of all other combinations examined.

\section{Avoidance is independent of embryonic age}

To determine whether the striking difference in outgrowth pattern observed in these chamber experiments was dependent on the embryonic age from which retinal and tectal cells originated, tissues of different ages were combined and assessed for retinal ganglion penetration of tectal areas. The embryonic ages examined span the developmental period in which retinal ganglion axons encounter the tectum in vivo and begin to sort out according to activity-independent guidance cues. Retinal explants prepared from $\mathrm{E} 6, \mathrm{E} 7$, and $\mathrm{E} 8$ ( $n=23,10$, and 7, respectively) displayed consistent outgrowth patterns; axons from temporal retinae stopped at the boundary of posterior tectal cells, whereas in the same dish axons from nasal retinae extended into the same tectal cell areas. Tectal cells dissociated from E5/6, E8, and E10/11 ( $n=6,29$, and 5, respectively) caused no deviation from the normal pattern of retinal outgrowth, i.e., retinal ganglion cell fibers from temporal retinae stopped at posterior tectal cell boundaries regardless of their embryonic age. Thus, of the combinations of retinal and tectal ages cultured, none displayed temporal retinal ganglion fibers invading the dissociated posterior tectal cells.

\section{Avoidance is independent of neuronal activity}

To determine whether fibers from temporal retinae stop at posterior tectal cell boundaries as a result of activity-dependent or activity-independent mechanisms, chamber experiments were prepared in the presence of TTX, which blocks $\mathrm{Na}^{+}$-dependent action potentials. In eight separate preparations, no difference 

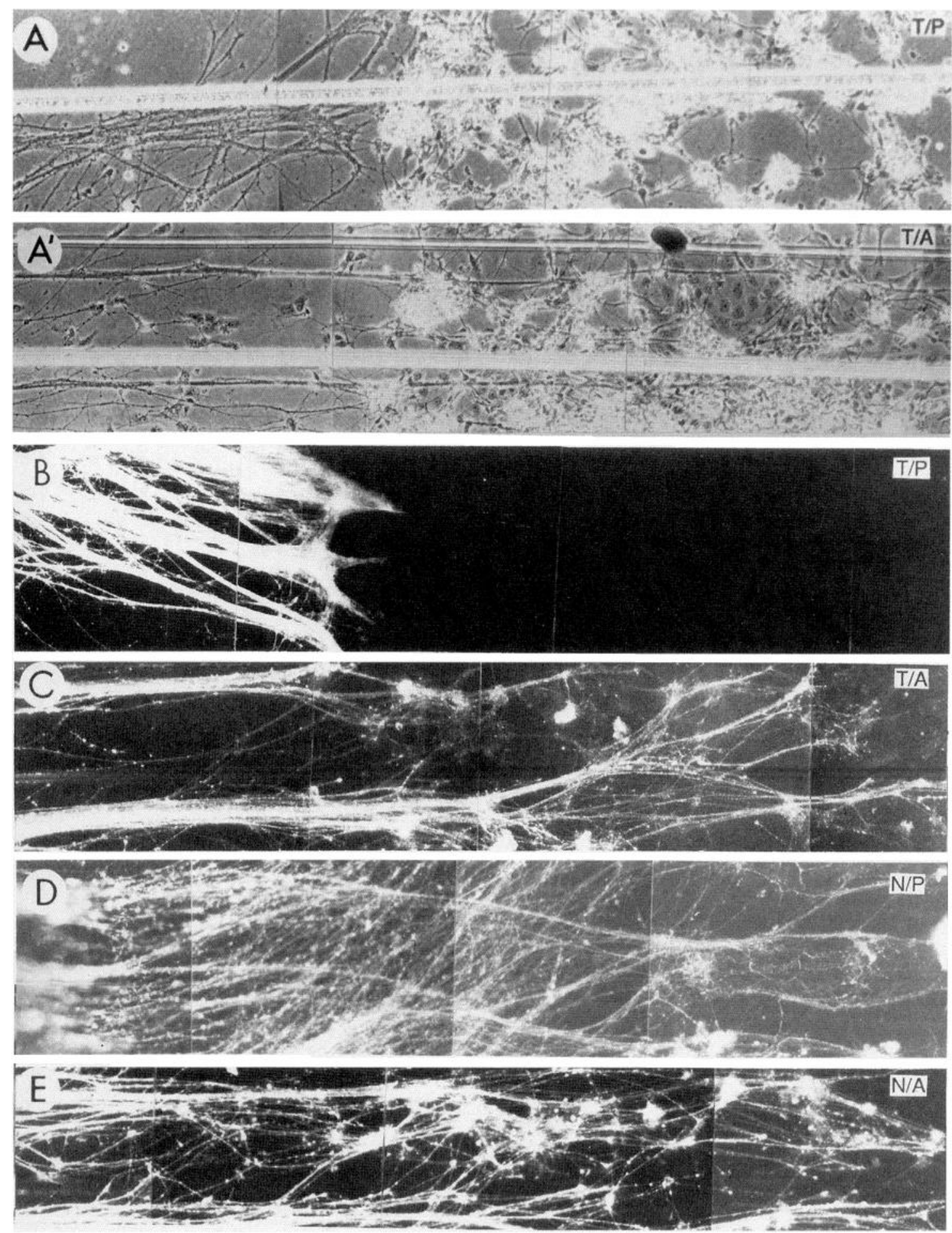

Figure 2. Examples of retinal ganglion cell outgrowth patterns as their axons intersect areas with dissociated tectal cells obtained from either anterior or posterior regions of the tectum. The barrier has been removed immediately after positioning of the retinal explant (to the left of photomontages) in each example, and the tectal cell boundary is aligned in all photomontages. $A$, Phase-contrast images showing axons from temporal retinal explants (E6) approaching dissociated cells from posterior $(A)$ and anterior $\left(A^{\prime}\right)$ regions of the tectum (E8). Axons extending from a temporal retinal explant characteristically fail to invade cells dissociated from posterior tecta $(A)$, but in parallel experiments show no signs of stopping at anterior tectal cells $\left(A^{\prime}\right)$. $B-E$, Forty-eight hours after axons extend from retinal explants, a Di-IC ${ }_{18}$-soaked strip of nitrocellulose filter paper is placed directly on the axons (just to the left of the field of view). Outgrowth is allowed to continue for another $24 \mathrm{hr}$ to enable complete labeling. Temporal axons clearly fail to invade dissociated posterior tectal cells $(B)$, while extending up to millimeters across cells dissociated from anterior tecta $(C)$. Nasal axons show similar, abundant invasion across cells dissociated from posterior $(D)$ or anterior $(E)$ tecta. Scale bar, $0.2 \mathrm{~mm}$. 


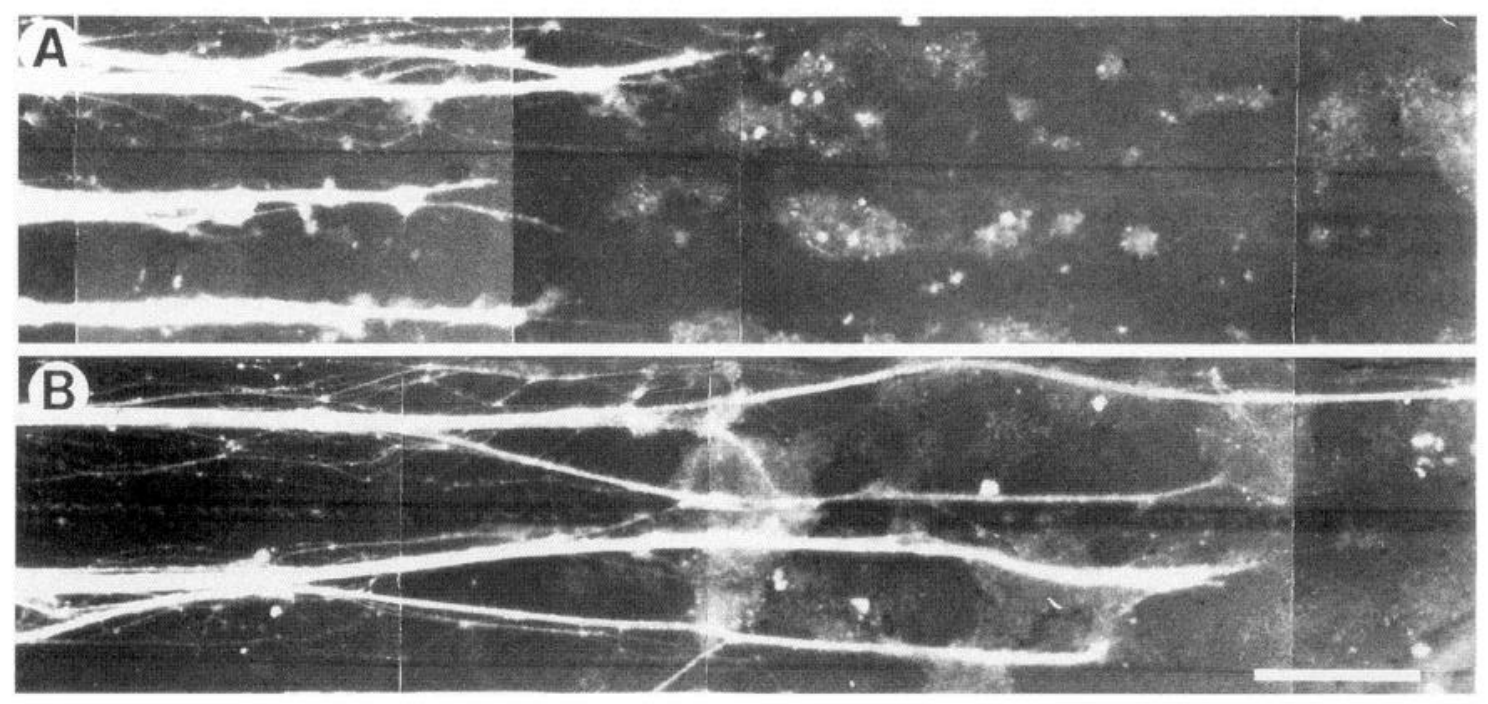

Figure 3. Retinal ganglion axons from temporal regions invade dissociated posterior tectal cells in the presence of PI-PLC, but not in the absence. These cultures were prepared side-by-side, and the photomontages were aligned such that the tectal cell boundaries align vertically. $A$, In control cultures, temporal axons stop at the boundary of posterior tectal cells. $B$, Addition on days 1 and $2 \mathrm{of} 100 \mathrm{mU} / \mathrm{ml} \mathrm{PI-PLC}$, then diluted to $20 \mathrm{mU} / \mathrm{ml}$ after $4 \mathrm{hr}$, enabled significant temporal fiber extension across posterior tectal cells $(B)$, which never occurred in control cultures $(A)$. Scale bar, $0.1 \mathrm{~mm}$.

could be detected between the outgrowth pattern observed in the presence of TTX (1. $\mu \mathrm{M})$ versus control dishes, which were prepared simultaneously and equivalently except for the omission of TTX. All fibers from temporal retinae stopped at the posterior tectal cell boundary, whereas nasal fibers in the same dishes continued to elongate into the posterior tectal cells. Thus, this difference in outgrowth pattern and inability of temporal fibers to penetrate posterior tectal cell areas represents an activityindependent process.

\section{Avoidance is dependent on contact}

In the present experiments, guidance could have occurred by diffusible factor(s) released from posterior tectal cells (causing temporal retinal ganglion fibers to stop prematurely) or by factor(s) that required retinal ganglion fibers to contact the posterior tectal cells and subsequently stop and retract. Examination of fixed preparations revealed thin membranous material connecting retinal ganglion fascicles to dissociated tectal cells, which suggested that contact had occurred. To determine unequivocally whether contact was evident during the exclusion of temporal fibers from posterior tectal areas, time-lapse recordings were made of chamber experiments. In five of five such preparations, intimate contact between retinal ganglion fiber tips and posterior tectal cells appeared before cessation and retraction of temporal retinal ganglion cell outgrowth. Long-term (4-12 hr) recordings allowed an assessment of hundreds of retinal ganglion axons encountering tectal areas. Encounters and retractions continued throughout the entire recording period and appeared to account for subsequent fasciculation and the bulbous endings of fascicles. Because small, thin retraction fibers often appeared to remain attached to tectal material, these may account for the stretched membrane material spanning the gap between bulbous fascicle endings and the tectal cell boundary observed in fixed preparations. Thus, contact appears to be involved in the exclusion of temporal fibers from posterior tectal areas. Taken together with previous results, contact-dependent, activity-independent guidance appears sufficient to account for the most prominent outgrowth patterns displayed by retinal explants cocultured with dissociated tectal cells.

\section{Avoidance is sensitive to PI-PLC}

To evaluate whether proteins attached to tectal cell surfaces via GPI anchorage (Ferguson and Williams, 1988; Cross, 1990; Englund, 1993) were determinant of the outgrowth patterns observed in the present experiments, PI-PLC was applied to the living cocultures before and during the period of contact between extending retinal ganglion axons and living tectal cells. PI-PLC treatment removes proteins attached via GPI structures (Sundler et al., 1978; Low and Saltiel, 1988; Stahl et al., 1990a). In the present experiments, we first assessed whether PI-PLC directly affects outgrowth from retinal explants or dissociated tectal cells. Addition of PI-PLC $24 \mathrm{hr}$ after explantation caused growth cones to collapse at concentrations greater than $\sim 10 \mathrm{mU} / \mathrm{ml}$, but this collapse was transient and growth cones recovered spontaneously after durations of 1-24 hr in continuous exposure to $<50 \mathrm{mU} / \mathrm{ml}$ PI-PLC. Concentrations sustained at $\geq 50 \mathrm{mU} / \mathrm{ml}$ caused relatively permanent changes in axonal morphology (blebbing and kinking of established axons). Addition of PI-PLC ( $\leq 100 \mathrm{mU} / \mathrm{ml})$ did not visibly affect the morphology of dissociated tectal cells.

In retinotectal cocultures, outgrowth of retinal ganglion axons after encounter with dissociated tectal cells was found to be sensitive to treatment with PI-PLC. PI-PLC was added 24 and 48 $\mathrm{hr}$ after explantation, and retinal ganglion fiber extension across tectal cells was assessed at $\sim 64 \mathrm{hr}$. The response of temporal retinal ganglion fibers at the border of posterior tectal cells was affected in each of the dishes receiving PI-PLC $(n=21)$. Fibers from temporal retinae appeared to maintain their contact and show less evidence of retraction from the posterior tectal cell boundary when treated with as little as $5 \mathrm{mU} / \mathrm{ml}$ PI-PLC. In dishes receiving higher concentrations of PI-PLC $(60-100 \mathrm{mU} / \mathrm{ml}$ for 4 $\mathrm{hr}$, then diluted to $20 \mathrm{mU} / \mathrm{ml}$ ), temporal axons actually extended across posterior tectal cells (Fig. 3). Such extension had never occurred in countless control experiments $(n>100)$ over a 16 month period using several different media and a variety of surfaces. The temporal fiber extension across posterior cells in PI-PLC was substantial $(467 \pm 106 \mu \mathrm{m})$ and significant $(p \leq$ $0.005)$, whereas side-by-side control dishes showed nearly no such temporal extension $(62 \pm 47 \mu \mathrm{m})$. Extension of temporal axons 
across anterior tectal cells and nasal axons across posterior tectal cells appeared unaffected $(n=9)$. In only a few dishes receiving PI-PLC was temporal fiber outgrowth across posterior tectal cells as substantial $(>1 \mathrm{~mm})$ as that across anterior tectal cells or nasal fiber extension across either population of tectal cells. This limited outgrowth suggests that residual repulsive components may be constantly active in these cultures.

\section{Cellular identification of tectal cells responsible for guidance of retinal ganglion axons}

Seven different antibodies indicated the presence of two general classes of cell types within dissociated tectal cell cultures (Fig. 4). Even after only $48 \mathrm{hr}$ in culture, nearly all tectal cells with processes $(\geq 90 \%)$ stained positive for neuronal markers such as polyphosphorylated neurofilaments (RT-97) and tetanus toxin fragment $C$ (Neale et al., 1988) (Fig. 4B). All cells with processes in cultures older than $48 \mathrm{hr}$ were positive for neuronal markers. These cells also stained positive with two different monoclonal antibodies to Ng-CAM. These cells displayed neuronal phenotypes and often had major processes of $>100 \mu \mathrm{m}$. Their cell bodies were small $(\leq 15 \mu \mathrm{m})$ and round and possessed between one and three major processes. Shorter, thin, more tortuous processes emanated from their cell bodies, although these were much more common in older cultures ( $\geq 4 \mathrm{~d}$ ). These cells also were negative for a number of non-neuronal markers, such as anti-glial fibrillary acidic protein (anti-GFAP) and anti-vimentin (Fig. $4 C, E$ ). The faint appearance of these cells in Figure $4 C$ is a result of inadequate optical separation. No anti-vimentin staining of these cells was observed in cultures that were not previously well labeled with neuron-specific antibodies (Fig. 4D,E). Thus, according to morphological and immunohistochemical criteria, these cells will be referred to as neurons.

The remaining cells [cells that were negative for each of the markers that labeled tectal neurons (Fig. 4B)] labeled specifically for vimentin-associated molecules (3A7) and for vimentin (R5 and H5; Fig. 4C,E). These R5/H5-positive cells displayed large, flattened morphologies; most were symmetric without processes. R5 and H5 have been used previously to identify chick tectal radial glia (Vanselow et al., 1989; Galileo et al., 1990; Gray and Sanes, 1992; Herman et al., 1993). These cells will be referred to as neuroepithelial, non-neuronal, or presumptive glial cells. Taken together, the immunohistochemical properties of the dissociated tectal cells enabled two general types of cells to be classified reliably: neuronal and neuroepithelial cells.

\section{Examination of growth cone encounters with specific target cell types}

To determine whether contact with only particular classes of tectal cells results in the avoidance behavior exhibited by fibers from temporal retinae, high-resolution time-lapse recordings were made as retinal ganglion growth cones encountered individual tectal cells. Tectal cells were identified as neuronal or neuroepithelial by morphological characteristics, which were consistent with their immunohistochemical properties. Retinal ganglion cell growth cones displayed a variety of behaviors in the initial few minutes after encountering tectal cells, generally showing either stopping and retracting, pausing, or unhindered continuation of outgrowth. Observed growth cone behaviors were grouped into four distinct categories, ranging from the most aversive to the most affirmative, and are summarized in Table 1 . The type of behavior a growth cone exhibited was dependent on whether the contacting growth cone originated in nasal or temporal regions of
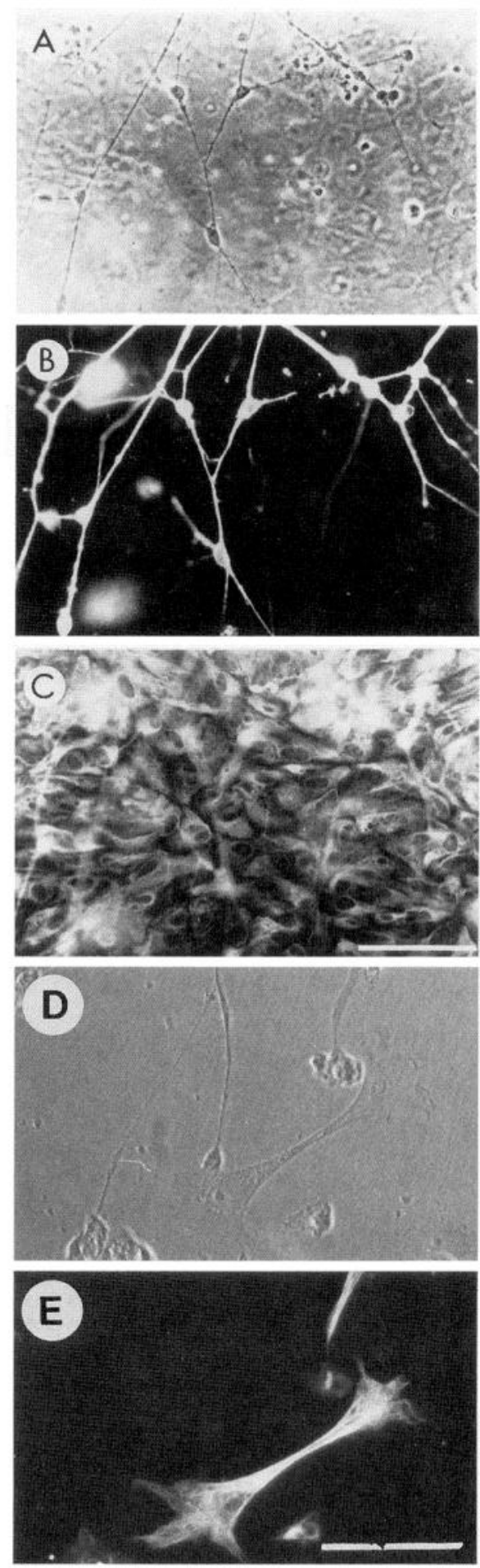

Figure 4. Dissociated tectal cells (E8) display two immunodistinctive cell types in culture. A single field of view is shown $(A-C)$ with phase contrast, and immunospecific staining of neuronal and non-neuronal cells. $A, \mathrm{~A}$ phase-contrast image demonstrates the dramatic difference in morphology between neuroepithelial cells (cells with broad, flattened morphologies) and neurons (cells with long, thin processes; relatively small, circular soma). Neurons label specifically with a number of neuronal-specific antibodies, including polyphosphorylated neurofilament, tetanus toxin, and $\mathrm{Ng}$-CAM. $B$, Tetanus toxin/fragment $\mathrm{C}$ immunofluorescence demonstrates the absence of neuroepithelial staining, and the relatively bright labeling of neurons. $C$, Neuroepithelial cells label specifically with antivimentin antibodies, whereas neurons do not. A second field of view $(D$, $E$ ) from a 2-d-old culture of dissociated E8 tecta demonstrates the specificity of $\mathrm{H} 5$ for cells with non-neuronal morphologies. Scale bars, $0.1 \mathrm{~mm}$. 


\begin{tabular}{|c|c|c|c|c|c|}
\hline $\begin{array}{l}\text { Retinae } \rightarrow \text { Tecta } \\
\text { Cell Type }\end{array}$ & $(n)$ & Retract & Attenuate & Track & Traverse \\
\hline \multicolumn{6}{|c|}{ Temporal $\rightarrow$ Posterior } \\
\hline Neuron & $(69)$ & 57 & 0 & 0 & 12 \\
\hline Neuroepithelia & (59) & 6 & 42 & 7 & 4 \\
\hline \multicolumn{6}{|c|}{ Temporal $\rightarrow$ Anterior } \\
\hline Neuron & $(10)$ & 0 & 0 & 1 & 9 \\
\hline Neuroepithelia & (10) & 1 & 7 & 0 & 2 \\
\hline \multicolumn{6}{|l|}{ Nasal $\rightarrow$ Posterior } \\
\hline Neuron & (13) & 0 & 0 & 0 & 13 \\
\hline Neuroepithelia & (21) & 1 & 9 & 5 & 6 \\
\hline \multicolumn{6}{|l|}{ Nasal $\rightarrow$ Anterior } \\
\hline Neuron & (10) & 0 & 0 & 0 & 10 \\
\hline Neuroepithelia & (35) & 2 & 30 & 3 & 0 \\
\hline
\end{tabular}

Growth cones of embryonic chick retinal ganglion cells responded to encounter with optic tectal cells according to their respective origin in retinae (Temporal or Nasal regions) or in tecta (Posterior or Anterior regions). Growth cone behavior ranged from negative interactions causing sudden collapse and retraction (Retract) to more positive interactions involving attenuation of outgrowth (Attenuate), turning alongside (Track), or direct extension on top of or across (Traverse) encountered optic tectal cells. The total number of encounters $(n)$ and the particular type of response are indicated for each category.

the retinae, whether the tectal cells originated in anterior or posterior regions, and specifically whether the tectal cell was a neuron or not.

\section{Encounter with tectal neurons}

Growth cones from explants of temporal retinae encountering neurons from posterior tecta displayed a characteristic aversive response: growth cones lost lamellipodia, withdrew filopodia, and subsequently the axon retracted ("Retract;" Fig. 5). As little as one filopodium from a temporal growth cone contacting a posterior tectal neuron was sufficient to cause the entire growth cone to collapse and retract away. The response of temporal growth cones to posterior tectal neurons occurred rapidly (Fig. $7 A-C$ ); within the first minute after contact, growth cones showed signs of collapse and retraction. Across the growth cone, filopodia were lost and lamellipodia pulled back. Retraction of the entire process ensued rapidly within the next few minutes. The response of growth cones appeared severe-growth cones usually retracted $>40 \mu \mathrm{m}$. Even after retraction, a remaining thin membrane often was left attached to the tectal cell. Occasionally, retracting retinal ganglion axons could reform new growth cones and resume outgrowth (Fig. 7A).

The repulsive behavior described was highly dependent on contact by temporal retinal ganglion cell growth cones with posterior tectal neurons (Fig. 8). More than $80 \%$ of temporal growth cones encountering posterior neurons retracted. This strong, negative reaction represented an aversive behavior significantly dependent on the original location of the tectal cell. For example, more retractions occurred between temporal growth cones and posterior neurons $(83 \%, n=69)$ than between temporal growth cones and anterior cells $(5 \%, n=20 ; p<0.0001)$, nasal growth cones and posterior cells $(3 \%, n=34 ; p<0.0001)$, or nasal growth cones and anterior cells $(4 \%, n=45$; $p<0.0001)$. Also, significantly more retractions occurred after temporal growth cone encounter with posterior tectal neurons when compared to contact with presumptive glia from posterior tecta $(10 \%, n=59$; $p<0.0001)$. It is clear that neurons from posterior tecta are selectively aversive to growth cones from temporal retinae.
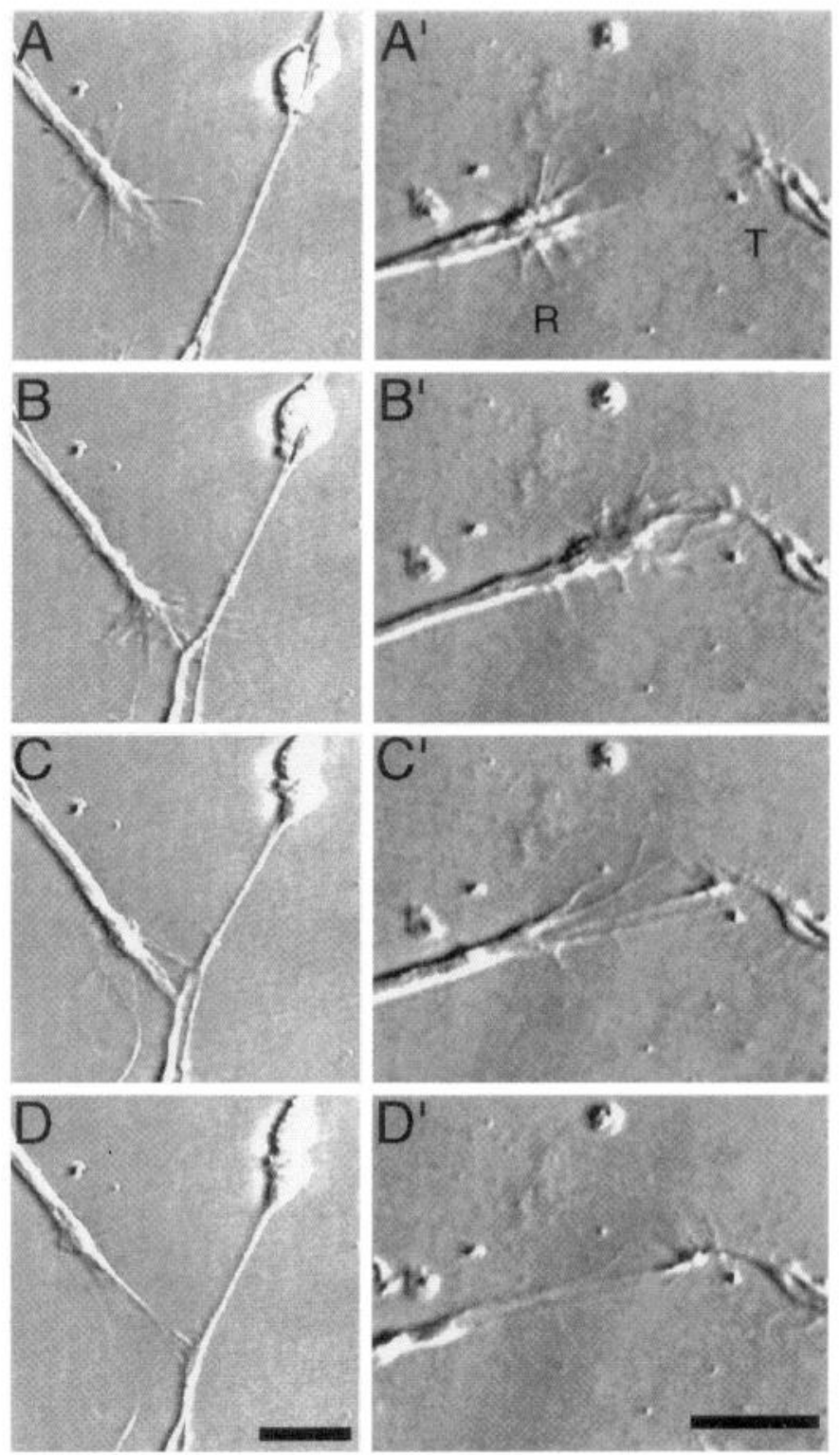

Figure 5. Time-lapse sequences demonstrate the response of retinal ganglion cell growth cones from explants of temporal regions of retinae to posterior tectal neurons. $A-D$, Temporal growth cones contacting posterior tectal neurons show a dramatic collapse and begin to retract within minutes. Retraction can leave temporal growth cones $>50 \mu \mathrm{m}$ from the tectal neuron, although often a thin, membranous material remains attached. Relative to contact, frames were recorded at $-9,1,5$, and $12 \mathrm{~min}$, respectively. $A^{\prime}-D^{\prime}$, A growth cone from temporal retinae $(R)$ encounters a growth cone extending from a posterior tectal neuron $(T)$. As in this example, all such encounters evoked immediate retraction of the retinal ganglion cell growth cones. Growth cones from posterior tecta did not respond reciprocally, usually showing no detectable change in motility. The substrate is laminin-coated plastic and thus does not appear uniform. Relative to contact, frames were recorded at $-5,0,5$, and $15 \mathrm{~min}$, respectively. Scale bars, $10 \mu \mathrm{m}$.

Retinal ganglion cell growth cones that did not collapse and retract from tectal neurons appeared to continue with little indication of slowing or change in growth cone motility ("Traverse"). This scenario describes the response of temporal growth cones to anterior tectal neurons ( $9 / 10$ individual growth cone encounters assessed) and nasal growth cones to either anterior $(10 / 10)$ or posterior (13/13) tectal neurons. Growth cones from temporal 
retinae crossed posterior tectal neurons significantly less often $(12 / 69 ; p<0.0001)$. Thus, in response to encounters with dissociated tectal neurons, all but one retinal ganglion axon displayed either of only two types of reactions: collapse and immediate retraction (57/69 temporal to posterior encounters) or an unabated continuation past seemingly ignored neurons (32/33 of all other retinal-to-tectal encounters).

\section{Retraction from posterior tectal neurons is dependent on site contacted}

Growth cones originating from temporal retinae encountered posterior tectal neurons at particular positions along the tectal cell surface: at the tectal somata, along the tectal process, and even with tectal growth cones. Interestingly, the responses of temporal retinal ganglion cell growth cones to the subcellular domains of posterior tectal cells were not identical: tectal growth cones appeared to provoke the most repellent effects, eliciting collapse and immediate retraction in all encounters ( 20 of 20$)$. Neuronal cell bodies ( 6 of 9 ) and processes ( 30 of 39 ) were less aversive to temporal growth cones ( $p<0.02$ and $p<0.01$, respectively), although encounter with these structures still did elicit considerable collapse and retraction (75\% of encounters). Thus, when growth cones on elongating retinal ganglion axons encountered developing tectal neurons from posterior regions, a strong aversive response nearly always occurred, especially if contact was with the motile tectal growth cone.

Interactions between retinal ganglion cell growth cones and tectal growth cones were a dynamic spectacle (Fig. $5 A^{\prime}-D^{\prime}$ ). Contact appeared to exert a change in behavior exclusively from the temporal growth cone; posterior tectal growth cone motility continued unabated. Collapse and retraction of temporal growth cones appeared to occur after as little as filopodial contact, i.e., temporal retinal ganglion cell filopodia contacting posterior tectal filopodia. Because of the highly motile interaction, however, it is difficult to exclude the possibility of brief contact between filopodia and lamellipodia by either growth cone. Such filopodial interaction also occurred along tectal processes, which often had small, filopodia-like processes emanating from along their shaft. Again, filopodial contact appeared extremely aversive to the temporal growth cone, which retracted immediately.

\section{Encounter with tectal neuroepithelial cells}

Retinal ganglion cell growth cones displayed a much different response after encountering non-neuronal cells compared to encounters with neurons from optic tecta, and the response was substantially less dependent on the topographic origin of the cells (Fig. 8). Instead of the all-or-none response (sudden retraction or unobstructed continuation) that was observed when retinal ganglion cell growth cones encountered tectal neurons, growth cones usually paused and "dithered" at the edge of the neuroepithelial cells (Fig. 6A-D). Details of this interaction varied, but, typically, elongation of the retinal ganglion axon was attenuated at the edge of the large, flattened cells, whereas growth cone filopodia and lamellipodia remained motile ("Attenuate"). This intimate association could persist for hours (Fig. 7D; also, note the image displayed in Fig. $6 D$ was captured $>1 \mathrm{hr}$ after contact and the growth cone is still motile). Retinal ganglion axons often extended with these neuroepithelial cells as the cell migrated along the dish surface. Filopodia continued to sweep across the cell surface, but they rarely attached directly to it. Eventually, growth cones often collapsed their filopodia to appear as more blunt endings, but
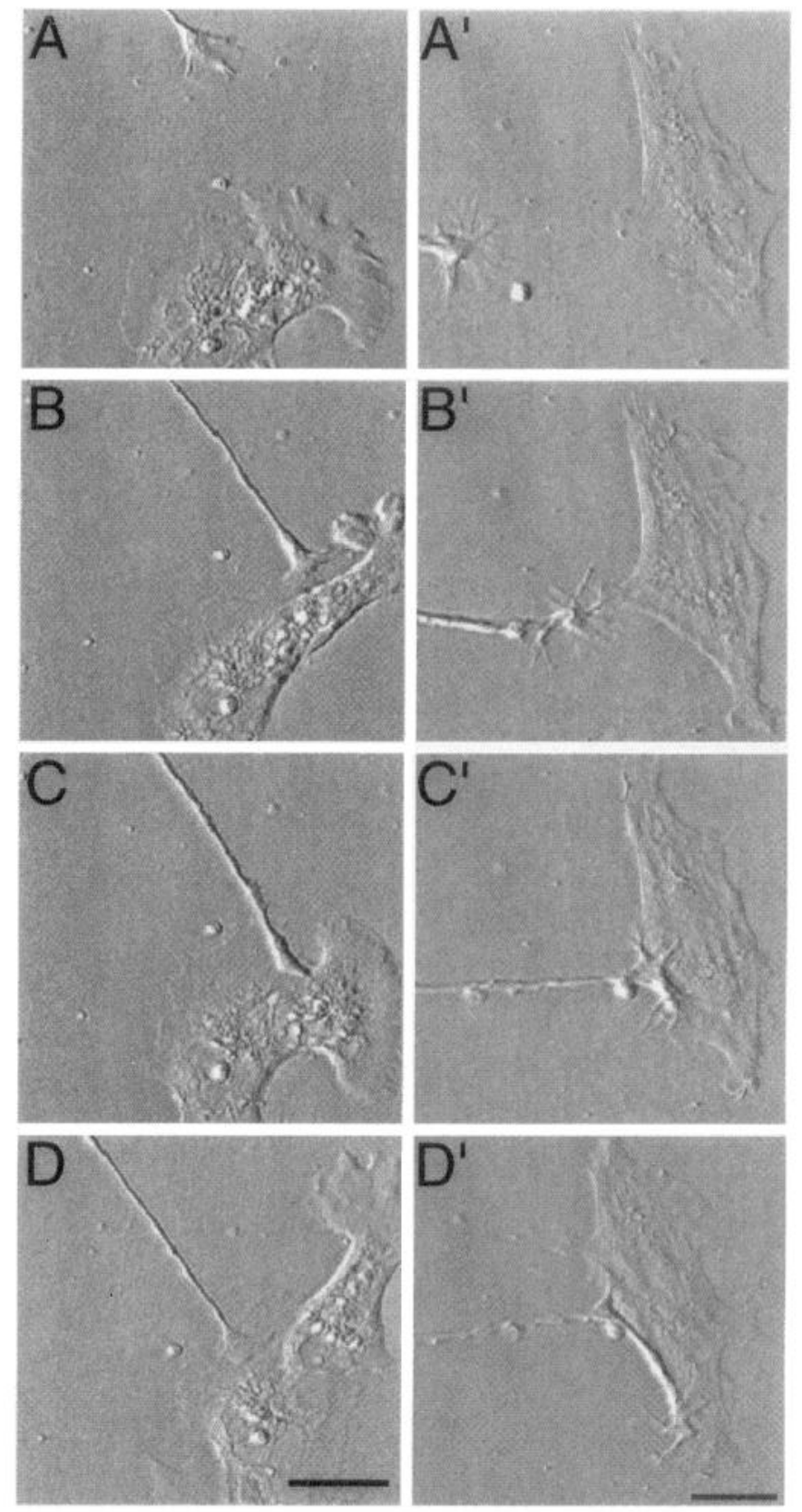

Figure 6. Retinal ganglion cell growth cone behavior after contact with tectal neuroepithelial cells was neither topographically specific nor strongly aversive. $A-D$, Temporal growth cones contacting neuroepithelial cells from posterior tecta rarely retract, but often show an attenuation of growth cone motility and axonal extension. Growth cone motility typically persists for at least several minutes and, in most encounters, for the duration of recording. The behavior represented in these panels is characteristic of retinal ganglion cell growth cones from either nasal or temporal regions contacting neuroepithelial cells from either anterior or posterior tecta. Relative to contact, frames were recorded at $-23,5,38$, and $74 \mathrm{~min}$, respectively. $A^{\prime}-D^{\prime}$, After encounter with neuroepithelial cells, growth cones can turn and track alongside, a response that occurred significantly more often when nasal growth cones contacted posterior cells. Relative to contact, frames were recorded at $-16,1,10$, and $30 \mathrm{~min}$, respectively. Scale bars, $10 \mu \mathrm{m}$.

despite this relatively collapsed morphology, lamellipodia remained motile for up to hours. Some of the contacting retinal ganglion fibers eventually retracted (Fig. $7 F$ ), but this retraction was delayed considerably: the time from contact to retrac- 

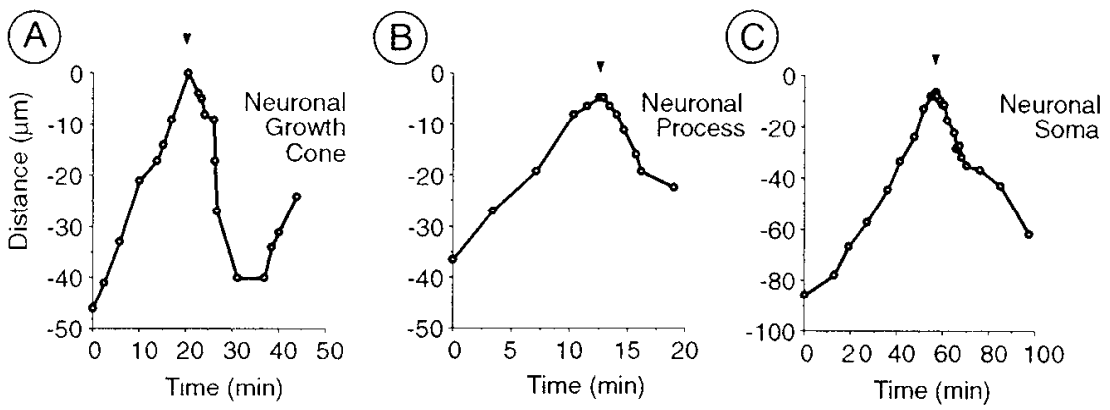

Figure 7. Kinetics of encounters between growth cones from temporal regions of retinae and posterior tectal cells. $A-C$, After encounter with postcrior tectal ncurons (arrowhead), temporal growth cones immediately collapse and retract, indicated by the negative outgrowth rate. Retraction kinetics are similar when retinal ganglion cell growth cones contact posterior tectal growth cones $(A)$, neurites $(B)$, or somata $(C)$. $D-F$, Contact with non-neuronal cells isolated from all rcgions of tecta attenuate retinal ganglion cell outgrowth, although growth cone motility continues. Elongation of axons can remain arrested at the edge of the cell for up to hours $(D)$ and, in rare circumstances, display a delayed retraction $(F)$

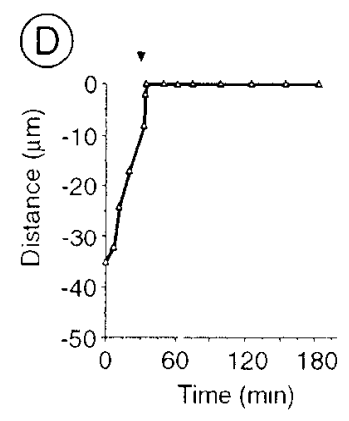

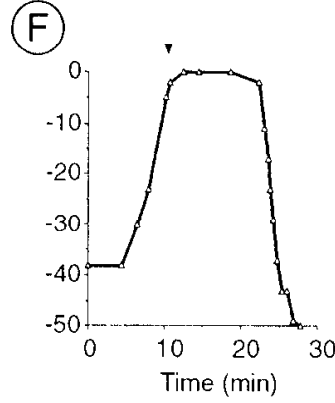

tion varied between 16 and $90 \mathrm{~min}$. Delayed retraction after contact with neurocpithelial cells did not appear well correlated with the initial contact. The response of growth conescohering at the cell edge and yet remaining motile-was observed commonly after contact with neuroepithelial cells, but never with tectal neurons. Such behavior accounted for $71 \%$ of the encounters between temporal retinal ganglion cell growth cones and posterior neuroepithelial cells, and generally was the most common response as retinal ganglion cell growth cones contacted neuroepithelial cells from optic tecta (Fig. 8).

Although the majority of all retinal ganglion axons exhibited attenuated outgrowth as they encountered neuroepithelial cells, fewer growth cones from nasal retinae encountering neuroepithelial cells from posterior tecta resulted in such behavior. Only $43 \%$ of nasal growth cones encountering posterior neuroepithelial cells resulted in attenuation of outgrowth, but after encounter with the same cells from anterior tecta, extension was arrested twice as often $(86 \% ; p<0.001)$. The difference could be accounted for by growth cones continuing to elongate or track along the presumptive glia: nasal growth cones exhibited a more positive response to neuroepithelial cells from their target area (posterior) more frequently $(52 \%)$ than from their nontarget area (9\%). Temporal growth cones paused and dithered similarly after encounter with neuroepithelial cells from either anterior or posterior tecta $(70$ and $71 \%$, respectively; $p>0.9$ ).

After encountering neuroepithelial cells, numerous retinal ganglion cell growth cones turned to track along the cell's edge, extending along its boundary with the laminin-coated substratum ("Track"). These growth cones avoided a direct path across the flattened cells, but also did not pause and dither at the sitc of initial contact (Fig. 6 $A^{\prime}-D^{\prime}$ ). Tracking along a cell did not appear to slow retinal ganglion axon outgrowth (Fig. $7 E$ ). Retinal ganglion cell growth cones that encountered neuroepithelial cells at a more shallow angle, rather than head-on, appeared even more likely to exhibit this tracking behavior. Some growth cones did grow directly across the flattened portions of the neuroepithelial cells without any detectable change in direction or elongation rate. This traversal only occurred when the growth cone extended across the most flattened portion of the cell (i.c., away from the nucleus) and when the retinal ganglion cell growth cone could span the presumptive glia in $<1-2$ growth conc diameters. Interestingly, nasal growth cones extended more frequently along or onto posterior neuroepithelial cells (their natural target population) compared with encountering anterior neurocpithelial cells $(p<$ $0.0002)$. Temporal growth cones tracked similarly along or onto anterior and posterior neurocpithelial cells (19 and $20 \%$ of respective encounters; $p>0.9$ ).

In $\leq 11 \%$ of all encounters with neuroepithelial cells, retinal ganglion cell growth cones collapsed and immediately retracted. This infrequent retraction to neuroepithelial cells was not dependent on the topographic origin of the retinal ganglion cell (nasal vs temporal; $5 \% n=56,10 \% n=69$, respectively; $p>0.3$ ) or the tectal cell (anterior vs posterior; 7\% $n=45,9 \% n=80$, respectively; $p>0.6)$.

Thus, contact with neuroepithelial cells tended to attenuate retinal ganglion fiber outgrowth regardless of the original location of either the retinal ganglion cell or tectal cell. However, nasal growth cones turned and extended along or even on top of presumptive glia isolated from their target-matched location (posterior tecta) significantly more frequently. Retraction from neuroepithelial cells was rare and independent of the origin of either the contacting growth cone or neuroepithelial cell.

\section{DISCUSSION}

Cellular localization and discrimination of guidance cues distributed across embryonic optic tecta provide insight into the developmental mechanisms that establish retinotectal topography. Similar to the well documented and striking aversion for posterior tectal fragments exhibited by axons from temporal retinae in other assays, repellent components were revealed in retinotectal cocultures and were found to be sensitive to PI-PLC. In the present experiments, repulsive activity was localized to individual cells from posterior tecta, specifically by their constituent neurons. Non-neuronal cells, on the other hand, failed to express repulsive activities. Whether from anterior or posterior tectal regions, these presumptive glia attenuated outgrowth of ganglion axons from both temporal and nasal retinae; however, nasal growth cones 


\section{A Encounter with Tectal Neurons}
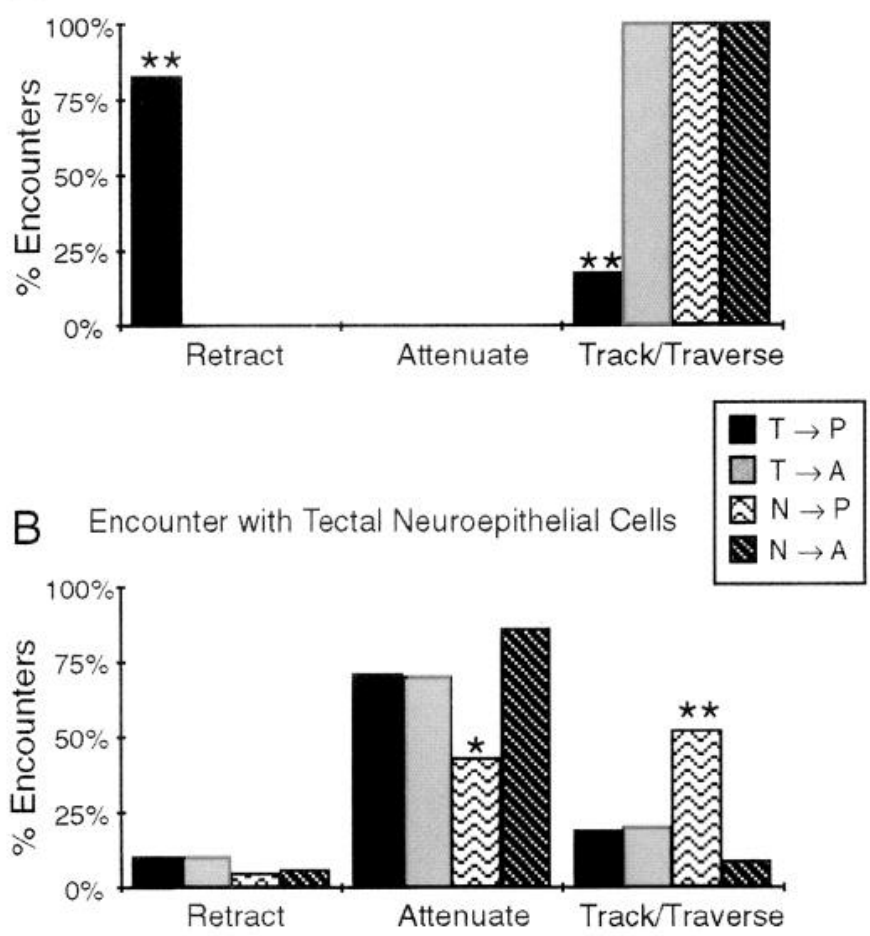

Growth Cone Behavior

Figure 8. Histogram of encounters demonstrate the striking difference in growth cone responses between neurons isolated from different regions of retinae or tecta and between retinal ganglion fiber encounter of tectal neurons versus non-neuronal cells. $A$, Only contact between temporal growth cones and posterior neurons evokes a consistent collapse and retraction. Contact between temporal growth cones and anterior neurons and between nasal growth cones and either anterior or posterior neurons never yielded a negative response. $B$, Contact with neuroepithelial cells from all regions of the tecta by either nasal or temporal growth cones primarily resulted in the attenuation of retinal ganglion axon outgrowth, but without retraction. Nasal growth cones were more likely to continue elongating across or at the edge of neuroepithelial cells from posterior regions. $T \rightarrow P, T \rightarrow A$, Temporal growth cones encounter posterior (black bars) or anterior (gray bars) tectal cells, respectively; $N \rightarrow P, N \rightarrow A$, nasal growth cones encounter posterior (zig-zag bars) or anterior (striped bars) tectal cells, respectively. ${ }^{* *} p<0.0005,{ }^{*} p<0.005$ relative to same response from other regions of retinae and tecta.

more frequently tracked along or on top of these cells when dissociated from posterior regions. Taken together, the results suggest that during development of the visual system, activityindependent guidance may involve multiple guidance cues distinctly present on neuronal and non-neuronal target cell populations. Furthermore, they demonstrate that a single tectal cell expresses adequate guidance information to dramatically affect retinal ganglion cell outgrowth.

\section{Aversive material in posterior tecta}

Encounters with living cells in the present assay yielded results consistent with previous assays using tectal membrane fragments (Bonhoeffer and Huf, 1982; Walter et al., 1987a,b; Cox et al., 1990; Müller et al., 1990; Waltef et al., 1990b; Baier and Bonhoeffer, 1992; Davenport et al., 1994): components repulsive for temporal axon extension and sensitive to PI-PLC are expressed in posterior tecta at the developmental ages when optic fibers are extending across tecta in vivo. In previous culture assays using tectal membrane fragments, cellular material from all constituent cells was combined. The present results indicate that repellent activity may have resulted primarily from contact with membrane fragments originating on posterior neurons, because only when growth cones from temporal retinae encountered neurons from posterior tecta did an extremely aversive response occur. More than $80 \%$ of temporal growth cone-to-posterior neuron encounters resulted in collapse and retraction, whereas only $10 \%$ of encounters with posterior non-neuronal cells resulted in such aversive behavior-an amount not significantly more than if nasal growth cones encountered posterior non-neuronal cells or if temporal growth cones encountered anterior non-neuronal cells. Thus, previous assays examining repulsive guidance activities in posterior tecta primarily may have been detecting the response of growth cones to factor(s) expressed on tectal neurons. Because such a high percentage of posterior neurons evoked growth cone collapse and retraction in the present assay, it is unlikely that repulsive activity resides on only a minor subpopulation of retinorecipient neurons. Consequently, the aversive guidance activity discovered on tectal neurons is apt to influence retinotectal topography during development.

During development, optic fibers extend in the stratum opticum (Vanegas, 1984; Mey and Thanos, 1992; Yamagata et al., 1995) and, based on the present results, axons from temporal retinae would be expected to continue elongating until intimately contacting posterior tectal neurons. Indeed, temporal axons have been observed to overshoot their anterior targets in vivo (Nakamura and O'Leary, 1989). This overshoot may not reflect a general lack of repulsive components in vivo as has been suggested (Simon and O'Leary, 1992), but rather may indicate the timing of contact between temporal growth cones and developing posterior tectal neurons. If this is true, the timing of the appearance of tectal neuronal processes at or near the tectal surface may affect map generation by serving as one of the mechanisms excluding temporal axons from posterior tecta.

In the chick, as optic fibers initially are projecting across the tectal surface, most tectal processes lie below the glial endfeet. Tectal processes elongating vertically toward the surface would first present their growth cones as the substrate for mediating guidance cues to encroaching optic fibers. In the present assay, growth cones from posterior tecta were especially repellent, causing all of the contacting growth cones from temporal retinae to collapse and retract. Precise timing of retinal and tectal development to ensure that their respective growth cones meet head-on at the tectal surface may not be essential, however. Retinal ganglion axons display filopodia-like extensions early in development over a wide area of the tectum (Rager and von Oeynhausen, 1979; Sachs and Schneider, 1984; Thanos and Bonhoeffer, 1987; Vanselow et al., 1989; Simon and O'Leary, 1992). Such filopodia-like extensions may serve a sensory role, much like growth cone filopodia (Chien et al., 1993; Davenport et al., 1993) detecting guidance information across the axon's projection. Given the present results, a functional role for the optic fiber side branches could encompass detection of guidance cues localized to constituent neurons, which initially may lie beyond the reach of advancing growth cones.

\section{Neuroepithelial cells attenuate axonal elongation}

In contrast to their dramatic response to tectal neurons, very few retinal ganglion cell growth cones retracted from non-neuronal cells. The retractions that did occur were not selective for cells from anterior or posterior tecta or for growth cones from nasal or temporal retinae. Instead, contact with non-neuronal cells gener- 
ally attenuated outgrowth of retinal ganglion axons. It is plausible that repellent guidance signaling may originate uniquely on posterior tectal neurons, whereas non-neuronal cells may serve a more general role. For example, non-neuronal cells may provide the substrate for retinal axon elongation as they extend across the tecta. As has been shown in chick retinae (Halfter el al., 1987; Stier and Schlosshaucr, 1995), recent experiments with tectal cryosections (Yamagata and Sanes, 1995) and tectal glial endfeet (Kröger and Nichörster, 1990) suggest chick radial glia serve as a permissive substrate without obvious repellent activity. The nonspecific attenuation observed in the present experiments may explain in part the slowed outgrowth of retinal ganglion axons as they advance across the tecta (Harris et al., 1987). The tendency for later-arriving axons to fasciculate with earlier fibers (Thanos and Bonhoeffer, 1983; Vanselow et al., 1989) further indicates that although the tectal surface may be permissive, it is not ideal for rapid outgrowth. Thus, attenuating retinal ganglion cell growth cones may represent a fundamental guidance mechanism and may explain, in part, why axons continue on the tectal surface toward their target regions rather than invading the carliest tecta encountered. This is especially relevant for nasal axons, which must extend over many millimeters to reach their target areas in posterior tecta.

After reaching posterior tecta, nasal axons may respond specifically to cues expressed on non-neuronal cells. It was previously noted that nasal axons appear immune to the aversive material in posterior tecta (Walter et al., 1987a), and in fact prefer to extend on membrane fragments from posterior tecta (von Boxberg et al., 1993). In the present investigation, nasal axons extended on or tracked alongside presumptive glia from their appropriate (posterior) tectal region. As a result, extension into deeper retinorecipient layers in vivo, which likely involves tracking along radial glia (Vanselow et al., 1989), may occur with a higher probability when nasal axons reach posterior tecta. Taken together, the results suggest that non-neuronal cells could affect optic fibers in at least two important ways: generally slowing axonal extension as fibers reach the tectum and serving as a substratum for appropriate axons to turn and track into deeper layers.

A priori, we had predicted that repulsive guidance cues in chick tecta would be expressed especially on non-neuronal cells. This prediction was bascd primarily on two facts: (1) endfeet of radial glia are in direct contact with extending retinal ganglion fibers in vivo; and (2) previous experiments using dissociated Xenopus cultures (Johnston and Gooday, 1991) discovered that temporal growth cones collapsed more frequently after encounter with glia from posterior tecta than from anterior tecta (responses to neurons were not examined). Recently, a repellent axon guidance signal (RAGS) located in posterior chick tecta was identified and may be expressed in radial glia (Drescher et al., 1995), further suggesting that radial glia express repellent cues. Radial glia are the only significant glial population in either the developing frog or chick tecta. Two of the antibodies (R5 and H5) that specifically labeled the neuroepithelial cells in our cultures have been demonstrated previously to stain sclectively chick radial glia in vivo (Vanselow et al., 1989; Herman et al., 1993). Nevertheless, because there are no known markers specific for cultured radial glia, our neuroepithelial cells may not exclusively represent this cell population. Further experiments will be necessary to determine whether these neuroepithelial cells, which did not induce growth cone collapse, express RAGS, other putative guidance molecules, and/or represent the same cell population as examined by Johnston and Gooday (1991).

\section{Initial development of retinotectal topography}

The results suggest a model in which cues on both tectal neurons and non-neuronal cells are used to establish retinotectal topography. Initially, the majority of optic fiber outgrowth continues in the superficial stratum opticum. Radial glia provide a substratum that supports attenuated outgrowth of incoming retinal ganglion axons. Outgrowth continues until encounter with specific guidance cues in posterior tecta: aversive cues on posterior neurons repel temporal fibers, whereas distinct cues on posterior glia attract nasal fibers into deeper tectal layers. Axons from central retinae would be first to encounter such cues: temporal fibers detecting aversive neuronal cues would be forced to invade deeper layers of the central, but anterior tecta; nasal fibers contacting posterior radial glia would turn and track toward deeper layers of central, but posterior tecta. Thus, central-temporal and central-nasal axons would reach their appropriate, separate target areas. Later, temporal axons from more peripheral regions of the retinae would have only more anterior regions of the tecta available for penetration; nasal axons would continue to track down the carliest unoccupied, more posterior regions. Together, such a spatially and developmentally regulated guidance system could provide the basis for rudimentary topography.

\section{REFERENCES}

Baicr H, Bonhocffer F (1992) Axon guidance by gradients of a targetderived component. Science 255:472-475.

Baicr H, Klostermann S (1994) Axon guidance and growth cone collapse in vitro. Neuroprotocols: A companion to methods. Neurosciences 4:96-105.

Bastmeyer M, Stuermer CA (1993) Behavior of fish retinal growth cones encountering chick caudal tectal membranes: a time-lapse study on growth cone collapse. J Neurobiol 24:37-50.

Bonhoeffer F, Gierer A (1984) How do retinal axons find their targets on the tectum? Trends Neurosci 7:378 381 .

Bonhoeffer F, Huf J (1982) In vitro experiments on axon guidance demonstrating an anterior-posterior gradient on the tectum. EMBO J $1: 427-431$.

Campenot RB (1977) Local control of neurite development by nerve growth factor. Proc Natl Acad Sci USA 74:4516-4519.

Cantino D, Sisto Daneo L (1973) Synaptic junctions in the developing chick optic tectum. Experientia 29:85-87.

Chang S, Rathjen FG, Raper JA (1990) Neurite outgrowth promoting activity of $\mathrm{G} 4$ and its inhibition by monoclonal antibodies. J Neurosci Res 25:180-186.

Cheng HJ, Nakamoto M, Bergemann AD, Flanagan JG (1995) Complementary gradients in expression and binding of ELF-1 and Mek4 in development of the topographic retinotectal projection map. Cell 82:371-381.

Chien C-B, Rosenthal EE, Harris WA, Holt CE (1993) Navigational errors made by growth cones without filopodia in the embryonic $X$ enopus brain. Neuron 11:237-251.

Constantine-Paton PM, Cline HT, Debski E (1990) Patterned activity, synaptic convergence, and the NMDA receptor in developing visual pathways. Annu Rev Neurosci 13:129-154.

Cox E, Müller B, Bonhoeffer F (1990) Axonal guidance in the chick visual system: posterior tectal membranes induce collapse of growth cones from the temporal retina. Neuron 2:31-37.

Cross GAM (1990) Glycolipid anchoring of plasma membrane proteins. Annu Rev Cell Biol 6:1-34.

Davenport RW, Dou P, Rehder V, Kater SB (1993) A sensory role for neuronal growth cone filopodia. Nature 361:721-724.

Davenport RW, Löschinger J, Huf J, Jung J, Bonhoeffer F (1994) Retinal axons suddenly stop elongating after significant extension onto gradients of posterior tectal material. Soc Neurosci Abstr 20:1065.

Dräger UC, Edwards DL, Barnstable CJ (1984) Antibodies against tilamentous components in discrete cell types of the mousc retina. J Neurosci 4:2025-2042.

Drescher U, Kremoser C, Handwerker C, Löschinger J, Noda M, Bonhoeffer F (1995) In vitro guidance of retinal ganglion cell axons by 
RAGS, a $25 \mathrm{kDa}$ tectal protein related to ligands for Eph receptor tyrosine kinases. Coll 82:359-370.

Englund PT (1993) The structure and biosynthesis of glycosyl phosphatidylinositol protein anchors. Annu Rev Biochem 62:121-138.

Ferguson MAJ, Williams AF (1988) Cell-surface anchoring of proteins via glycosyl phosphatidylinositol structures. Annu Rev Biochem 57:285-320.

Fields RD, Nealc EA, Nelson PG (1990) Effects of patterned electrical activity on neurite outgrowth from mouse sensory neurons. J Neurosci 10:2950-2964.

Fraser SE, Perkel DH (1990) Competitive and positional cues in the patterning of nerve connections. J Neurobiol 21:51-72.

Galileo DS, Gray GE, Owens GC, Majors J, Sanes JR (1990) Neurons and glia arise from a common progenitor in chicken optic tectum: demonstration with two retroviruses and cell type-specific antibodies. Proc Natl Acad Sci USA 87:458-462.

Gierer A (1987) Directional cues for growing axons forming the retinotectal projection. Development 101:479-489.

Giloh H, Sedat JW (1982) Fluorescence microscopy: reduced photobleaching of rhodamine and fluorescein protein conjugates by $n$-propyl gallate. Sciencc 217:1252-1255.

Godement P, Bonhocffer F (1989) Cross-species recognition of tectal cues by retinal fibers in vitro. Development 106:313-320.

Gray GE, Sanes JR (1992) Lineage of radial glia in the chicken optic tectum. Development 114:271-283.

Halfter W, Newgreen DF, Sauter J, Schwarz U (1983) Oriented axon outgrowth from avian embryonic retinac in culture. Dev Biol 95:56-64.

Halfter W, Reckhaus W, Kröger S (1987) Nondirected axonal growth on basal lamina from avian embryonic neural retina. J Ncurosci $7: 3712-3722$.

Harris W, Holt C, Bonhoeffer F (1987) Retinal axons with and without their somata, growing to and arborizing in the tectum of xenopus cmbryo: a time-lapse video study of single fibers in vivo. Development $101: 123-133$.

Herman JP, Victor JC, Sanes JR (1993) Developmentally regulated and spatially restricted antigens of radial glial cells. Dev Dyn 197:307-318.

Johnston AR, Gooday DJ (1991) Xenopus temporal retinal neurites collapse on contact with glial cells from caudal tectum in vitro. Development 113:409-417.

Kaprielian Z, Patterson PH (1994) The molecular basis of retinotectal topography. Bioessays 16:1-11.

Kenimer JG, Habig WH, Hardegree MC (1983) Monoclonal antibodies as probes of tetanus toxin structure and function. Infect Immun 42:942-948.

Klostermann S (1993) Untersuchungen zur intrazellulären Signaltransduktion der axonalen Lenkung im retinotectalen System. PhD thesis, Universität Tübingen, Germany.

Kröger S, Niehörster L (1990) Isolation, characterization, and substrate properties of the external limiting membrane from the avian embryonic optic tectum. J Neurosci Res 27:169-183.

Lemmon V, McLoon SC (1986) The appearance of an L1-like molecule in the chick primary visual pathway. J Neurosci 6:2987-2994.

Low MG, Saltiel AR (1988) Structural and functional roles of glycosylphosphatidylinositol in membranes. Science 239:268-275.

Mey J, Thanos S (1992) Development of the visual system of the chick-a review. J Hirnforsch 33:673-702.

Müller B, Stahl B, Bonhoeffer F (1990) In vitro experiments on axonal guidance and growth-cone collapse. J Exp Biol 153:29-46.

Nakamura H, O'Leary DD (1989) Inaccuracies in initial growth and arborization of chick retinotectal axons followed by course corrections and axon remodeling to develop topographic order. J Neurosci 9:3776-3795

Neale EA, Koh J, Habig WH (1988) Fragment C of tetanus toxin is a non-toxic label for living neurons. Soc Neurosci Abstr 14:547.

O'Leary DD (1992) Development of connectional diversity and specificity in the mammalian brain by the pruning of collateral projections. Curr Opin Neurobiol 2:70-77.

Panzica GC, Viglictti-Panzica CV (1981) Electron microscopy of synaptic structures in the optic tectum of developing chick embryos. Bibl Anat $19: 167-173$

Rager G (1976) Morphogenesis and physiogenesis of the retino-tectal connection in the chicken. I. The retinal ganglion cells and their axons. Proc R Soc Lond [Biol] 192:331-352.
Rager G, von Oeynhausen B (1979) Ingrowth and ramification of retinal fibers in the developing optic tectum of the chick embryo. Exp Brain Res 35:213-227.

Roskies AL, O'Leary DD (1994) Control of topographic retinal axon branching by inhibitory membrane-bound molecules. Science 265:799-803.

Sachs GM, Schneider GE (1984) The morphology of optic tract axons arborizing in the superior colliculus of the hamster. J Comp Neurol 230:155-167.

Sanes JR (1993) Topographic maps and molecular gradients. Curr Opin Neurobiol 3:67-74.

Simon DK, O'Leary DD (1990) Limited topographic specificity in the targeting and branching of mammalian retinal axons. Dev Biol 137:125-134.

Simon DK, O'Leary DD (1992) Responses of retinal axons in vivo and in vitro to position-encoding molecules in the embryonic supcrior colliculus. Neuron 9:977-989.

Sperry RW (1963) Chemoaffinity in the orderly growth of nerve fiber patterns and connections. Proc Natl $\Lambda$ cad Sci US $\Lambda$ 50:703-710.

Stahl B, Müller B, von Boxberg Y, Cox EC, Bonhocffer F (1990a) Biochemical characterization of a putative axonal guidance molecule of the chick visual system. Neuron 5:735-742.

Stahl B, von Boxberg Y, Müller B, Walter J, Schwarz U, Bonhoeffer F (1990b) Directional cues for retinal axons. Cold Spring Harb Symp Quant Biol 55:351-357.

Stier H, Schlosshauer B (1995) Axonal guidanee in the chicken retina. Development 121:1443-1454.

Sundler R, Alberts AW, Vagelos PR (1978) Enzymatic properties of phosphatidylinositol inositolphosphohydrolase from Bacillus cereus. J Biol Chem 253:4175-4179.

Thanos S, Bonhocffer F (1983) Investigations on the development and topographic order of retinotectal axons: anterograde and retrograde staining of axons and perikarya with rhodamine in vivo. J Comp Neurol 219:420-430.

Thanos S, Bonhoeffer F (1987) Axonal arborization in the developing chick retinotectal system. J Comp Neurol 261:155-164.

Udin SB, Fawcett JW (1988) Formation of topographic maps. Annu Rev Neurosci 11:289-327.

Vanegas H (1984) Comparative neurology of the optic tectum. New York: Plenum.

Vanselow J, Thanos S, Godement P, Henke FS, Bonhoeffer F (1989) Spatial arrangement of radial glia and ingrowing retinal axons in the chick optic tectum during development. Brain Res Dev Brain Res 45:15-27.

Viclmetter J, Walter J, Stuermer CA (1991) Regenerating retinal axons of goldfish respond to a repellent guiding component on caudal tectal membranes of adult fish and cmbryonic chick. J Comp Ncurol 311:32l-329.

von Boxberg Y, Deiss S, Schwarz U (1993) Guidance and topographic stabilization of nasal chick retinal axons on target-derived components in vitro. Neuron 10:345-357.

Walter J, Alsopp T, Bonhoeffer F (1990a) A common denominator of growth cone guidance and collapse? Trends Neurosci 13:447-456.

Walter J, Müller B, Bonhoeffer F (1990h) Axonal guidance by an avoidance mechanism. J Physiol (Paris) 84:104-110.

Walter J, Henke FS, Bonhoeffer F (1987a) Avoidance of posterior tectal membranes by temporal retinal axons. Development 101:909-913.

Walter J, Kern VB, Huf J, Stolze B, Bonhoeffer F (1987b) Recognition of position-specific properties of tectal cell membranes by retinal axons in vitro. Development 101:685-696.

Wizenmann A, Thies E, Klostermann S, Bonhocffer F, Bahr M (1993) Appearance of target-specific guidance information for regenerating axons after CNS lesions. Neuron 11:975-983.

Wood JN, Anderson BH (1981) Monoclonal antibodies to mammalian neurofilaments. Biosci Rep 1:263-268.

Yamagata M, Sanes JR (1995) Lamina-specific cues guide outgrowth and arborization of retinal axons in the optic tectum. Development 121:189-200.

Yamagata M, Hcrman JP, Sanes JR (1995) Lamina-specific expression of adhesion molecules in developing chick optic tectum. J Neurosci 15: $4556-4571$ 